\title{
TAX EXCHANGE OF INFORMATION AND INTERNATIONAL COOPERATION IN BRAZIL *
}

\author{
Heloisa Estellita e Frederico Silva Bastos \\ O INTERCÂMBIO DE INFORMAÇÕES TRIBUTÁRIAS \\ E A COOPERAÇÃO INTERNACIONAL NO BRASIL
}

\begin{abstract}
GLOBALIZATION AND INTERNATIONALIZATION OF COMPANIES ARE PHENOMENA THAT NEED TO BE CONSIDERED BY MODERN TAX ADMINISTRATIONS. IN MANY SITUATIONS, SUCH AS TAX EVASION, HARMFUL TAX COMPETITION AND MONEY LAUNDERING, DOMESTIC STATUTES SEEM TO BE INEFFECTUAL IN A GLOBAL DIMENSION. TO COPE WITH THAT, NEW FORMS OF REGULATION AND REGULATORS EMERGE. UNDER THIS VIEW, AN EFFORT TOWARDS SIGNING INTERNATIONAL TREATIES, CONVENTIONS AND AGREEMENTS SEEMS TO BE A FEASIBLE SOLUTION. ThE BRAZILIAN LEGAL FRAMEWORK CONTAINS PRINCIPLES AND RULES THAT MAKE INTERNATIONAL COOPERATION AND EXCHANGE OF INFORMATION (EOI) WITH OTHER COUNTRIES POSSIBLE. FURTHERMORE, THE BRAZILIAN TAX ADMINISTRATION HAS WIDE-RANGING ACCESS POWERS TO OBTAIN INFORMATION FOR INTERNATIONAL EXCHANGE PURPOSES AND HAS THE TOOLS TO COERCIVELY PRODUCE SUCH INFORMATION. BRAZIL IS FOLLOWING THE RIGHT PATH TO IMPLEMENT INTERNATIONAL EXCHANGE OF INFORMATION STANDARDS. HOWEVER, THERE ARE SOME OBSTACLES THAT NEED TO BE FIXED FOR A MORE EFFICIENT IMPLEMENTATION OF THESE MECHANISMS. THIS ARTICLE EXAMINES SOME TOPICS OF THE BRAZILIAN LEGAL AND INSTITUTIONAL FRAMEWORK ON THE TAX EXCHANGE OF INFORMATION, SUCH AS A NEW MODEL OF APPROACH OF THE TAX ADMINISTRATION, THE TAX TRANSPARENCY AGENDA AND THE INTERNATIONAL AGREEMENTS ON EOI MATTERS, the Brazilian SUPREME COURT RULINGS UNDER
\end{abstract}

\section{RESUMO}

A GLOBALIZAÇÃO E A INTERNACIONALIZAÇÃO DAS EMPRESAS SÃO FENÔMENOS QUE PRECISAM SER CONSIDERADOS PELAS MODERNAS ADMINISTRAÇÕES TRIBUTÁRIAS. FISCALIZARE COMBATER A EVASÃO FISCAL, O PLANEJAMENTO TRIBUTÁRIO AGRESSIVO E A LAVAGEM DE DINHEIRO SOMENTE COM MEDIDAS DOMÉSTICAS TENDE A SER INÓCUO EM UMA DIMENSÃO GLOBAL. PARA LIDAR COM ESSE CENÁRIO, NOVAS FORMAS DE REGULAÇÃO E REGULADORES SÃO EXIGIDAS. SOB ESTE PONTO DE VISTA, UM ESFORÇO NO SENTIDO DE ASSINAR TRATADOS INTERNACIONAIS, CONVENÇÕES E ACORDOS PARECE SER UMA SOLUÇĀO VIÁVEL. O ARCABOUÇO LEGAL BRASILEIRO CONTÉM PRINCÍPIOS E REGRAS QUE TORNAM A COOPERAC̄AOO INTERNACIONAL E O INTERCÂMBIO DE INFORMAÇÕES (EOI) COM OUTROS PAISES POSSÍVEIS. ALÉM DISSO, A ADMINISTRAÇÃO TRIBUTÁRIA BRASILEIRA TEM AMPLOS PODERES DE ACESSO PARA OBTER INFORMAÇÕES PARA FINS DE INTERCÂMBIO INTERNACIONAL, ASSIM COMO CONTA COM FERRAMENTAS PARA PRODUZIR COERCITIVAMENTE TAIS INFORMAÇÕES. NESSE CONTEXTO, O BRASIL TEM REALIZADO GRANDES ESFORÇOS PARA ADEQUAR SUAS INSTITUIÇÕES E LEGISLAÇÕES AOS PADRÕES INTERNACIONAIS NO QUE TANGE À TROCA DE INFORMAÇÕES TRIBUTÁRIAS. NO ENTANTO, EXISTEM ALGUNS OBSTÁCULOS QUE PRECISAM SER OBSERVADOS PARA UMA EXECUÇÃO MAIS EFICAZ DESTES MECANISMOS. NESSE SENTIDO, ESTE ARTIGO SE PROPŌE A ANALISAR ALGUMAS QUESTŌES IMPORTANTES REFERENTES À MOLDURA JURÍDICA E INSTITUCIONAL BRASILEIRA NO INTERCÂMBIO DE INFORMAÇÕES 
BANK SECRECY AND THE RIGHTS OF BRAZILIAN TAXPAYERS REGARDING EOI.

\section{KEYWORDS}

GLOBALIZATION; TAX EVASION; EXCHANGE OF INFORMATION; INTERNATIONAL COOPERATION; TAX ADMINISTRATION.

\begin{abstract}
TRIBUTÁRIAS, TAIS COMO, A MUDANÇA DE PARADIGMA NA ATUAÇÃO DAS ADMINISTRAÇÕES TRIBUTÁRIAS, A AGENDA DA TRANSPARÊNCIA FISCAL E OS ACORDOS INTERNACIONAIS EM MATÉRIA EOI, AS DECISŌES DO SUPREMO TRIBUNAL FEDERAL SOBRE O SIGILO BANCÁRIO E OS DIREITOS DOS CONTRIBUINTES BRASILEIROS EM RELAÇÃO AO EOI.
\end{abstract}

\section{PALAVRAS-CHAVE}

GLOBALIZAÇÃO; EVASÃO FISCAL; INTERCÂMBIO DE INFORMAÇÕES; COOPERAÇÃO INTERNACIONAL; ADMINISTRAÇĀO TRIBUTÁRIA.

\section{LAW, GLOBALIZATION AND TAX ADMINISTRATION}

Current commercial operations perform in an environment where geographical boundaries are becoming less important. The phenomenon of globalization shortens distances and spreads information across the globe. In this context, the global competition among companies intensifies, especially in relation to reducing costs, taxation and in expanding into new markets.

Taxation is likely to be one of the main factors determining the movement of goods, capital, and man power (BLOCH; HEILEMANN, 1946, p. 1159). The mobility of people and information has led to harmful competitive practices ${ }^{1}$ on a global scale, damaging countries' ability to effectively enforce their tax and corporate laws. Thus, the ease of allocating people and investments and a significant lack of coordinated action between countries, make harmful tax competition, money laundering, CFC's (Controlled Foreign Corporation) and tax evasion very difficult to be controlled solely by domestic tax administrations.

Globalization and internationalization of companies are phenomena that need to be considered by modern tax administrations. While in the past fiscal policies were established in each country solely for domestic troubleshooting, with globalization and the free movement of capital, there is a sensitive change in how different tax systems and tax administrations interact with each other.

The current network society ${ }^{2}$ is subjected to a new model of legal system, in which a high level of information sharing is a key feature. The traditional legal tools are placed under discussion by the transformation of the States' relation in a global framework (RODOTTÀ, 2003, p. 1), in which domestic laws seem to be ineffectual. To cope with that, new forms of regulation and regulators emerge.

State sovereignty, citizenship, territory and jurisdiction are legal concepts that were built in the past and accompanied modernity allowing the construction of many national legal systems (RODOTTÀ, 2003, p. 1). These traditional concepts, however, are being challenged by constant scientific and technological innovation, as well as by a global network that surrounds and significantly reduces geographic boundaries. 
Under this view, an effort in signing of international treaties, conventions and agreements seems to be a feasible solution not only to adopt common and harmonized standards, but mainly to regulate singularities, that alone, cannot be concentrated only in the domestic dimension, as is the case of harmful tax competition, double taxation, tax fraud, and money laundering (BLOCH; HEILEMANN, 1946, p. 1169).

Trying to solve these issues only on the domestic level tends to be ineffective, given that globalization of economic activity undermines local legislative interventions and requires a more harmonious and shared action. In light of this scenario, one realizes the importance of supranational bodies in the study of Exchange of Information (EOI) on tax matters and the formulation of proposals that can be implemented jointly by the international community.

In this context, this article provides a short overview of the exchange of information in tax matters in a global perspective, examines the Brazilian institutional and legal framework supported by the international transparency agenda, its compliance with international agreements and conventions, and the specialized doctrine. It argues that some tools for efficient EOI in tax matters are limited either by local regulation or rulings of the Brazilian Supreme Court in connection to bank secrecy and individual privacy.

\section{THE EXCHANGE OF INFORMATION IN TAX MATTERS: AN OVERVIEW}

One of the main challenges for international tax law nowadays is how to ensure full effectiveness of domestic tax law regarding transactions with other countries and the consequent movement of capital. The first requirement for legal effectiveness is the knowledge, by the tax administration, about the economic operations of a specific taxpayer, otherwise it cannot apply and enforce the relevant provisions - it is a matter of efficacy and legality. The second requirement is a thorough knowledge of the whole economic transaction, as opposed to simply the domestic part of it - this is a matter of transparency. A point to stress is that, for the law to be fully applicable, regulation and efficient enforcement information is essential (GRECO, 2011, p. 177).

To illustrate the importance of the exchange of information and transparency in this global scenario, we quote one of the conclusions of the Second Conference on the Fight against International Tax Fraud and Evasion by promoting Transparency and Exchange of Information in Tax Matters (BERLIN - June 23, 2009):

They emphasized that transparency and Exchange of information in tax matters are the basis for a fair competition in a global economy and an equitable tax burden weighing on honest taxpayers. They confirmed that the fight against any form of tax offences is a shared responsibility of all countries and territories. ${ }^{3}$ 
Although it seems excessive to say that "we are our data" (RODOTTÀ, 2003, p. 10), it is nevertheless true that our social representation is increasingly entrusted to information disseminated in multiple personal or public databases and profiles. Therefore, a main issue of the exchange of information among different nations is to find a balance between, on one hand, giving and obtaining information that assists the enforcement of tax and criminal law and, on the other hand, respecting legality, fundamental rights and not jeopardizing other interests that each nation may have (BLOCH; HEILEMANN, 1946, p. 1169).

The main path encountered by the international community to seek this balance was by way of international treaties, conventions and agreements and global organizations that contributed to the standardization of some practices, so as to contribute to greater efficiency of the exchange of information between tax administrations. With international cooperation through treaties, agreements and conventions, nations commit themselves, amongst other things, to exchange information. According to the practice of information exchange, it is possible to stress five main methods used to do so in tax matters: (i) Automatic Exchange; (ii) Spontaneous Exchange; (iii) Exchange Upon Request; (iv) Simultaneous Tax Exchange; and (v) Tax Examinations Abroad.

Certain international organizations and forums can be identified for having already developed significant projects in the area of exchange of information on tax matters, namely: the Organization for Economic Co-operation and Development - OECD, ${ }^{4}$ the United Nations - UN, G20 - Finance Ministers Group, Global Forum on Transparency and Exchange of Information, the Pacific Association of Tax Administrators PATA, and the Joint International Tax Shelter Information Center - JITSIC.

A precursor of projects on exchange of information is the OECD Model Tax Convention on Income and on Capital. In 1963, the OECD drafted the first version of this model tax convention, ${ }^{5}$ already including the possibility of the exchange of information (article 266 ). From hereinafter, all subsequent Model Tax Conventions updates provide for this possibility.

One of the most important initiatives in this area is the Global Forum on Transparency and Exchange of Information, also created by the OECD, with the active participation of the G20 Finance Ministers. This Forum has 108 member countries, ${ }^{7}$ as well as nine international organizations acting as observers. ${ }^{8}$ It aims to establish international standards for tax cooperation and to ensure that all participating jurisdictions offer the same standard of international cooperation in tax matters. This international standard is outlined in the document's Terms of Reference ${ }^{9}$ and is evaluated through a Peer Review Group. ${ }^{10}$ To assist the evaluation, the Peer Review Group has developed ten essential elements of transparency and exchange of information for tax purposes. ${ }^{11}$ 


\section{TABLE 1 - THE IO ESSENTIAL ELEMENTS OF TRANSPARENCY AND EXCHANGE OF INFORMATION FOR TAX PURPOSES}

\section{A. AVAILABILITY OF INFORMATION}

A.1. JURISDICTIONS SHOULD ENSURE THAT OWNERSHIP AND IDENTITY INFORMATION FOR ALL RELEVANT ENTITIES AND ARRANGEMENTS IS AVAILABLE TO THEIR COMPETENT AUTHORITIES.

A.2. JURISDICTIONS SHOULD ENSURE THAT RELIABLE ACCOUNTING RECORDS ARE KEPT FOR ALL RELEVANT ENTITIES AND ARRANGEMENTS.

A.3. BANKING INFORMATION SHOULD BE AVAILABLE FOR ALL ACCOUNT-HOLDERS.

\section{B. ACCESS TO INFORMATION}

B.1. COMPETENT AUTHORITIES SHOULD HAVE THE POWER TO OBTAIN AND PROVIDE INFORMATION THAT IS THE SUBJECT OF A REQUEST UNDER AN EOI AGREEMENT FROM ANY PERSON WITHIN THEIR TERRITORIAL JURISDICTION WHO IS IN POSSESSION OR CONTROL OF SUCH INFORMATION.

B.2. THE RIGHTS AND SAFEGUARDS THAT APPLY TO PERSONS IN THE REQUESTED JURISDICTION SHOULD BE COMPATIBLE WITH EFFECTIVE EXCHANGE OF INFORMATION.

\section{EXCHANGING INFORMATION}

C.1. EOI MECHANISMS SHOULD PROVIDE FOR EFFECTIVE EXCHANGE OF INFORMATION.

C.2. THE JURISDICTIONS' NETWORK OF INFORMATION EXCHANGE MECHANISMS SHOULD COVER AL RELEVANT PARTNERS.

C.3. THE JURISDICTIONS' MECHANISMS FOR EXCHANGE OF INFORMATION SHOULD HAVE ADEQUATE PROVISIONS TO ENSURE THE CONFIDENTIALITY OF INFORMATION RECEIVED.

C.4. THE EXCHANGE OF INFORMATION MECHANISMS SHOULD RESPECT THE RIGHTS AND SAFEGUARDS OF TAXPAYERS AND THIRD PARTIES.

Source: (OECD, 2012).

In addition to these essential transparency elements, further conditions for an effective exchange of information are: (i) reliable information, (ii) foreseeability that tax provisions and information of a requesting jurisdiction is (iii.a) available, or can be (iii.b) made available, in a (iv) timely manner (OECD, 2012, p. 28).

Another important and complementary legal instrument that has been used to establish effective exchange of information between nations is the OECD Model of Agreement on the Exchange of Information on Tax Matters. The Tax Information Exchange Agreement - TIEA is intended to establish the standard of what constitutes effective exchange of information for the OECD's purposes. It is a more specific 
instrument than Double Tax Conventions and has been signed by an ever-growing number of countries in the last few years (ZAGARIS, 2010, p. 48-50).

\section{Graph 1 - TIEAs Signed AnNuAlly ${ }^{12}$}

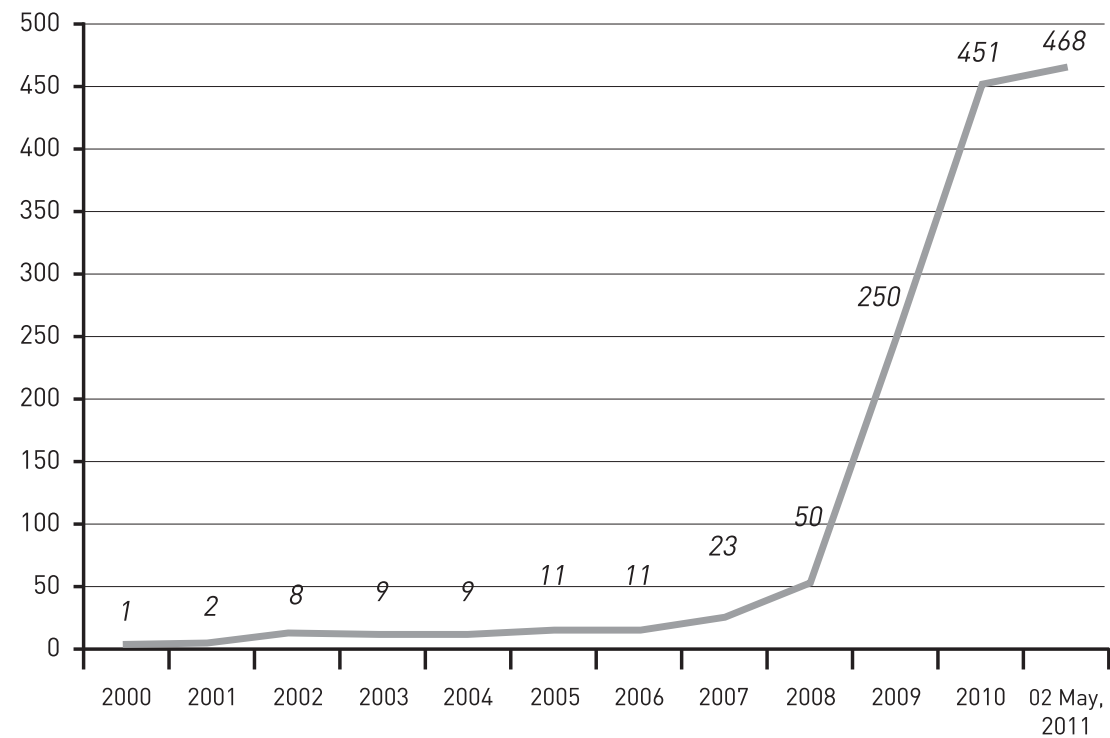

Source: (OECD, 2011).

The Joint International Tax Shelter Information Centre - JITSIC is another international organization that has also successfully developed standards for information sharing between tax administrations. Created in 2004, through an initiative of the tax administrations of Australia, Canada, United Kingdom and the United States, it aims to improve enforcement on harmful tax planning and information exchange in real time among tax authorities. The intention is to maximize the coordination of laws and fiscal policies of member countries and to combat double taxation and tax evasion. The work of these agents is done through the exchange of information and Joint Audits. ${ }^{13}$ It is noteworthy that the Joint Audit is also positive for the taxpayer because he/she presents records and explanations only once and receives a unified position of the tax administrations involved. Thus, the coordinated and harmonious action among tax administrations ensures certainty and predictability, along with more effective coercion to tax offenses. 
Recently, the United States Internal Revenue Service - IRS has started a new policy to enforce and control tax evasion by American citizens using the exchange of information between financial institutions and the government. The Foreign Account Tax Compliance Act - FATCA, that will enter into force in 2013, ${ }^{14}$ sets forth that the so-called Foreign Financial Institutions - FFIs and Non Financial Foreign Entities - NFFEs worldwide shall monitor and report to the U.S. tax authorities information on financial transactions of "U.S. persons" (citizens, companies, and U.S. corporations) residing or acting outside the United States. This new tax policy determines the application of a penalty to taxpayers who refuse to authorize such procedures. The penalty is to withhold $30 \%$ of any payment to be made to the account holder or U.S. investor, and a financial institution that does not comply or does not comply properly in reporting the information will also be subjected to withholding $30 \%$ on payments receivable from U.S. sources. ${ }^{15}$ Countries like France, Germany, Italy, Spain, Japan, Switzerland, Canada, Denmark, Finland, Guernsey, Ireland, Isle of Man, Jersey, Mexico, Netherlands and Norway ${ }^{16}$ have already signed bilateral agreements to implement FATCA regulation for financial institutions at a domestic level.

In sum, the work of these organizations and tax administrations reflect a new paradigm in the tax administration, allowing a network action presented by a high level of information sharing. It encourages the States themselves act in order to coordinate their actions and promote more transparency and enforcement in the international level.

\section{BRAZILIAN INSTITUTIONAL AND LEGAL FRAMEWORK ON EXCHANGE OF INFORMATION FOR TAX PURPOSES}

In recent years, Brazil has been establishing itself as a country that remodels and reconfigures its position towards a global scenario that increases its political and economic power. It developed a suitable environment for the internationalization of numerous Brazilian companies and also for many foreign companies that started to operate in the Brazilian market.

For this reason, the country is beginning to convert its role to assume a relevant economic and political position. In the words of John Prideaux, from The Economist, "Brazil used to be all promise. Now it is starting to deliver" (PRIDEAUX, 2009). This panorama is suggestive, but is also a clear indication that the tax administration and legal structure must be prepared to deal with global issues. To illustrate this argument, the Brazilian Tax Justice Seminar, organized by the Brazilian Council for Economic and Social Affairs, concluded that about $\$ 300$ to $\$ 400$ billion dollars have been remitted abroad without Brazilian government taxation. ${ }^{17}$ This information highlights how important is the exchange of information on tax matters in order to prevent and prosecute tax evasion and money laundering. Accordingly, we will examine 
some points of the Brazilian legal and institutional framework on the exchange of information.

First of all, Brazil's competent authority to deal with information exchange, federal taxes, as well as customs control, including efforts in counteracting money laundering, is the Secretariat of the Federal Revenue Service of Brazil (Secretaria da Receita Federal do Brasil - RFB), which is subordinated to the Minister of Finance. Nevertheless, the RFB, according to article 198 of the NationalTax Code - CTN, cannot exchange information for tax purposes unless they have a legal basis for doing so.

In spite of such provisions, Brazil has been signing Double Tax Conventions, which includes international exchange of information clauses, since the late 1960s (OECD, 2012, p. 7). Overall, Brazil has concluded 30 Double Tax Conventions - DTCs ${ }^{18}$ and seven Tax Information Exchange Agreements - TIEAs. ${ }^{19}$ Moreover, Brazil has recently signed the Multilateral Convention on Mutual Administrative Assistance in Tax Matters during the signing ceremony held at the G20 Summit in Cannes, France, in November 2011 (OECD, 2012, p. 61).

The Brazilian EOI legal framework contains principles and rules that make international cooperation and exchange of information with other countries possible. Under the Brazilian Constitution, one may find a guiding principle of cooperation between nations for the purpose of humanity progress (article $4^{\circ}$, IX). ${ }^{20}$ Moreover, and in a more specific sense, the Brazilian Tax Code provides for rules about international and domestic exchange of information. In its heading, Article $199^{21}$ provides for the exchange of information among the Federal Government, States, and Municipalities in the interest of national tax administration. ${ }^{22}$ Accordingly, an exclusive subdivision, entitled $\mathrm{COCIF}^{23}$ (Coordenação-Geral de Cooperação e Integração Fiscal) was set up within the RFB to coordinate the domestic tax integration among these three levels of the Federation.

In 2001, Complementary Law (Lei Complementar) n. 104 amended article 199 adding a sole paragraph to make it clear that Brazil can also mutually exchange tax information with other countries through international treaties, agreements and conventions. Reassuring the enforcement of these international instruments, the National Tax Code also provides, in article 98, that Double Tax Conventions (as well as other treaties in tax matters) prevail over the national legislation. Similarly to what happens in the national scenario, there is a subdivision of the Secretariat of Federal Revenue Service to deal specifically with international technical cooperation on tax matters, namely DIRIN 24 (Divisão de Relações Institucionais Internacionais).

These recent changes in the National Tax Code are part of the implementation of the Brazilian commitment to the Global Forum on Transparency and Exchange of Information for Tax Purposes guidelines (OECD, 2012, p. 18). As a member of this Forum since 2009, Brazil is engaged in implementing an international standard of transparency and exchange of information in tax matters. All members of the Global Forum, 
as well as jurisdictions identified as relevant to its work, are being evaluated under these international standards of transparency and EOI. This process is undertaken in two phases. Phase 1 reviews the quality of a jurisdiction's legal and regulatory framework for the exchange of information. Phase 2 reviews the practical implementation of that framework. Brazil was evaluated under the Phase 1 Peer Review requirements in the first half of 2011, and the Phase 2 Peer Review was launched on July $17^{\text {th }}, 2012$ (OECD, 2012, p. 5).

The Peer Review Report - Phase 1 stresses that RFB has significant information resources at its disposal, including ownership, identity, bank and accounting information both for domestic purposes and in response to a request from another jurisdiction by means of an international treaty (OECD, 2012, p. 49). In addition, the RFB has wide-ranging access powers to obtain information for international exchange of information purposes, and measures to coerce the production of such information. ${ }^{25}$ The RFB may also summon individuals and legal entities, taxpayers or not, and other related parties, to show books, documents and to provide any information required by the RFB in the exercise of its duties, within a stipulated period of time. ${ }^{26}$ In principle, there are no restrictions to the RFB's powers to directly interrogate individuals or seize documents. ${ }^{27}$ However, in the case of search and seizure of documents in private residences or professional premises, a court order is needed. ${ }^{28}$

The OECD conclusion about Brazilian legal and regulatory framework in Phase 1 Peer Review is the following:

The legal and regulatory framework for the availability of information is in place in Brazil. Ownership and identity information is maintained by relevant entities and arrangements. In addition, much information is filed with governmental authorities, in particular the tax authorities and the Public Trade Registrar. Similarly, a good framework exists which requires full accounting records, including underlying documentation, to be kept for at least five years (which corresponds to the statute of limitations period). Full bank information, including all records pertaining to account holders as well as related financial and transaction information, is available in Brazil. In addition, the tax authorities also collect certain bank data every year, such as the identity of all bank account holders and the monthly global amounts in deposit or saving accounts (OECD, 2012, p. 7).

The OECD Brazilian report informs that Brazil has many sources of information and also some enforcement mechanisms ${ }^{29}$ that compel taxpayers to provide information comprising civil, commercial, tax, regulatory and criminal (specifically in the sense of money laundering) laws. Brazilian tax authorities have a significant amount of ownership information at their disposal, which is kept up to date on a yearly basis 
(OECD, 2012, p. 25). According the OECD Phase 1 Peer Review, it is clear that Brazil has a complete database:

In respect of ownership and identity information, the comprehensive obligations consistently imposed on domestic and foreign companies, partnerships and foundations ensure that information is available either in the hands of public authorities (i.e. the Public Trade Registrar, the Civil Registry Office, the CVM, the BACEN, the RFB, etc.), the entity itself (articles of incorporation or shareholder register) or custodians (i.e. financial institutions and other entities supervised by the CVM). These obligations are complemented by the anti-money laundering legislation and rules concerning regulated activities (OECD, 2012, p. 19).

Therefore, the Brazilian legislation and institutional framework supports the EOI policies allowing availability, access of reliable information and powers to obtain information under civil, commercial, tax, regulatory, and criminal laws, where necessary. ${ }^{30}$

\section{EXCHANGE OF INFORMATION AND CONFIDENTIALITY}

International Information Exchange Instruments ${ }^{31}$ must contain confidentiality provisions that spell out specifically to whom the information can be disclosed and the purposes for which the information can be used. It must be noted that the joint application of the general domestic rules on confidentiality, in combination with the confidentiality provisions contained in Brazil's exchange of information agreements, would lead to the conclusion that information exchanged with foreign authorities may only be disclosed to persons or authorities, including courts and administrative bodies, concerned with the assessment, collection, prosecution, enforcement of the tax law in question or in criminal proceedings related to such taxes (OECD, 2012, p. 72).

The Brazilian Constitution ${ }^{32}$ does not expressly provide for bank confidentiality, ${ }^{33}$ but it protects the right to privacy as a fundamental right, even though this information may be provided to foreign competent authorities. Thus, there are no restrictions on the access to bank records (financial statements and other information) where (i) access is required during the course of a tax procedure ${ }^{34}$ and (ii) such examination is considered indispensable under a valid EOI request (OECD, 2012, p. 56). In particular, some bank information is already available to the RFB due to an automatic hand over of data by banks and financial institutions (OECD, 2012, p. 47). ${ }^{35}$

Yet, as a general rule, when the requested information is not in the possession of the RFB, it might summon the taxpayer to provide it or directly request the holder of this information to do so, without having to notify or obtain the consent of the person under assessment or investigation. 
By way of exception, the RFB needs to first summon the taxpayer to provide bank information ${ }^{36}$ because of the fundamental rights clause established in the Brazilian Constitution. Nevertheless, the taxpayer is not informed as to the reason why this information has been demanded. ${ }^{37}$ If the taxpayer, within a given timeframe, does not provide the information, Brazilian tax authorities can request it directly from financial institutions. ${ }^{38}$ It is important to stress that bank secrecy cannot be the basis for declining a request to provide information. A refusal based on a domestic tax interest ${ }^{39}$ requirement is not consistent with the international standard (OECD, 2012, p. 65).

Under Decree-Law n. 4.657/42, article 17, the Brazilian Tax Administration may decline an exchange of information request only if the disclosure of such information would be contrary to national sovereignty, public order or the principle of morality (OECD, 2012, p. 76).

Regarding criminal law, the anti-money laundering framework in Brazil is based on Law n. 9.613/98, which sets out the legal measures, such as the definition of money laundering crimes, preventive measures, the system for reporting suspicious activities, and the procedures for international cooperation. This law is the result of several international initiatives, such as the Vienna Convention, the Palermo Convention, the UN Convention against the Financing of Terrorism, the UN Convention against Corruption, and the FATF 40+9 Recommendations, among others (OECD, 2012, p. 16).

The Brazilian Financial Intelligence Unit ${ }^{40}$ (COAF), an agency within the Ministry of Finance, is actively involved in international initiatives related to the prevention of money laundering and financing of terrorism (OECD, 2012, p. 17). Since 2001, Complementary Law n. 105/01 introduced new rules on bank secrecy and extended the access powers of the COAF. In addition, Law n. 10.701/03 provided COAF with a broader authority to obtain information from third parties and created a national register of bank accounts (OECD, 2012, p. 17).

\section{I Brazilian Supreme Court decision on bank SeCrecy}

Despite the abovementioned rules providing the RFB with wide powers to have access to bank records, the Brazilian Supreme Court recently delivered a ruling demanding a court order authorizing the disclosure of such records by banks.

Although a set of lawsuits seeking the declaration of unconstitutionality of Complementary Law n. 105/2001 are pending before the Brazilian Supreme Court ${ }^{41}$ in regards to individual suits analyzed by the Court, the most recent decision was in favor of the taxpayer.

In Extraordinary Appeal n. 389.808, ${ }^{42}$ the plenary of the Court, by a tight majority of 6 to 4 , ruled that the provision granting the RFB with powers to directly access bank records for tax purposes violated constitutional rules.

In that case, the company was under tax assessment by the RFB, in which the authority was seeking bank records directly from financial institutions based on the 
provisions set up in Complementary Law n. 105/2001 and relevant regulation. The aim of requesting such information would be the assessment of whether the taxpayer was in debt with the RFB regarding some federal taxes. The tax authorities, as grounds to seek the disclosure of such information, neither raised allegations of tax evasion, nor sought to prove the commencement of a criminal investigation.

The Court held that direct access to bank records by government bodies violates constitutional provisions regarding privacy protection, and shall only be enforced by means of a court order authorizing the disclosure of such information.

Even though the decision was taken in an individual suit, and, therefore, has no binding effects with respect to any other Brazilian courts or persons not a party in the specific case, it expresses the latest position of the highest Brazilian Court on the matter.

That means that, although Complementary Law n. 105/2001 is still in force allowing tax authorities to obtain bank information directly from financial institutions, if the taxpayer challenges such requests before the Judiciary, there is a chance that he/she might be granted an injunction to halt the sharing of the information, until a court order is issued to allow the disclosure to the RFB.

As the Supreme Court clearly stated, its decision does not deprive tax authorities from having access to bank records whatsoever, but only that, in view of the constitutional right to privacy, the disclosure must be granted by a court order. It is evident that such a decision has effects on the international exchange of information for tax purposes where the taxpayer challenges the disclosure of bank records by way of an injunction. The decision also indicates that any treaty, cooperation agreement or tax administration policy, such as FATCA, allowing direct exchange of information of taxpayer's bank data might have its constitutionality challenged before the Supreme Court on the same grounds presented on the extraordinary appeal mentioned above.

\section{NATIONAL DEVELOPMENT STATUS IN TAX INFORMATION EXCHANGE AND INTERNATIONAL COOPERATION}

Brazil continues to expand its network and its infrastructure of exchange of information instruments and some new Double Tax Conventions and Tax Information Exchange Agreements are under different stages of negotiation. In addition to that, Brazil recently signed the multilateral Convention on Mutual Administrative Assistance in Tax Matters in November 2011.

It must be noted, however, that the timeframe to bring signed treaties into force by way of ratification can take several years in some cases. An example is the tax information exchange agreement between Brazil and the United States of America that was signed in March 2007 and ratified only in March 2013, clearly under pressure and with the view of the provisions arising from FATCA ${ }^{43}$ (ZAGARIS, 2013, p. 1). 
Accordingly, one of the recommendations made by the Global Forum is that Brazil ensures the ratification of signed treaties expeditiously (OECD, 2012, p. 8).

Nevertheless, there are a number of recent positive developments in the Brazilian legal and regulatory framework, relevant for exchange of tax information purposes. First, Decree n. 6.022/07 introduced in 2007, an electronic database that contains substantial tax and accounting records and other information of interest for the tax administrations of the Brazilian States and the RFB, as well as records on tax assessments on transactions performed by taxpayers. The project is known as SPED $^{44}$ - Electronic Tax Bookkeeping System and it is formed by two sub-projects: SPED-Accounting and SPED-Tax. SPED-Accounting 45 aims to replace company's account paper records for the obligation to transmit it in digital platform. ${ }^{46}$ SPEDTAX is applicable to all taxpayers subject to $\mathrm{ICMS}^{47}$ (State Tax) on the circulation of goods and services and/or to IPI (Federal Tax $)^{48}$, who must submit, in digital means and on a monthly basis, all relevant information concerning their activities and transactions relevant for the determination of these taxes (OECD, 2012, p. 18).

Another Brazilian initiative is the Electronic Invoice - NF-e. ${ }^{49}$ It is a document electronically issued and stored, aiming to document transactions performed by the circulation of goods and services. Non-compliance is punished with fines up to $50 \%$ of the amount of the transaction imposed on the issuer and/or recipient of the NF-e (OECD, 2012, p. 18).

A Normative Instruction by the Brazilian Revenue Service (RFB n. 811/2008 ${ }^{50}$ ) created the Declaration of Information on Financial Transactions (DIMOF). This report must be submitted by financial institutions electronically, twice a year, and must contain the monthly global amounts in deposit or savings and the taxpayer's identity. It is, thus, an important tool to keep the Brazilian tax administration database complete and updated.

These tools (SPED, NF-e and DIMOF) provide many benefits to the tax administration, as paper cost reduction, standardization of information among the different federative units, tax fraud reduction, simplification and streamlining of procedure, fast access to information, increased productivity by eliminating the auditor steps to collect the files, reduction of administrative costs, improving the quality of information and the ability to cross between the accounting and tax data. ${ }^{51}$

Apart from these domestic efforts, Brazil is also concerned with improving the international exchange of information on tax matters in accordance with Global Forum standards. For this reason, the Inter-ministerial Decree n. 236/2012 was issued to establish a taskforce ${ }^{52}$ to coordinate the Brazilian actions to suit the Global Forum standards. Additionally, Brazil has sought to increase its EOI agreements network and sought to review some treaties and conventions that do not foresee the exchange of information. 


\section{The USE OF MLATS TO OBTAIN INFORMATION FOR TAX PURPOSES}

While specific instruments of tax information exchange (both bilateral and multilateral) are not in force, the cooperation in criminal matters is open to the exchange of information for tax related offenses. ${ }^{53}$

Brazilian Law criminalizes tax evasion mainly under the provisions made by Law n. 8.317/90, according to which offenses of tax fraud can attract sentences from 2 to 5 years in prison, plus a fine. Tax evasion in connection to social securities taxes is also a criminal offense under the provisions of articles 168-A and 337-A of the Brazilian Penal Code, with penalty ranging from 2 to 5 years imprisonment, plus a fine.

Even prior to the ratification of the Brazil-US TIEA in 2013, co-operation between Brazil and United States in criminal matters was already efficient and effective under the terms of the Mutual Legal Assistance Treaty Brazil-U.S. (Decree n. 3.810/01). ${ }^{54}$ Although the agreement works solely for criminal matters, when it comes to tax fraud investigations, it was already a useful tool for obtaining evidence relevant to tax assessment, including bank records, from Brazil to the U.S. and vice versa.

The MLAT has already been used in some cases involving Brazilian nationals who were holding assets in US banks without declaring them to national authorities, which, besides amounting to a tax fraud offense, also constitutes a financial crime under Brazilian Criminal Law (Law n. 7.462/83). The US authorities have spontaneously sent bank records to Brazil, which were produced in criminal investigations and trials for the financial crimes and also shared with tax authorities for the sake of assessing the relevant taxes on income owed by Brazilian nationals.

This path could already have been taken to cooperate with US authorities when investigating tax fraud or tax evasion where relevant information was held by Brazilian nationals or authorities. A mutual legal assistance request under the Brazil-US MLAT will be dealt with by the Brazilian Central Authority (within the Ministry of Justice) in an efficient and expeditious way, especially where the request is solely for obtaining public records or serving documents, as the liaison will be direct between central authorities. However, if the request implies measures restricting fundamental rights, like searches and seizures, then a court's ruling will be required. The same applies, according to the latest precedent of our Supreme Court abovementioned, in connection to the disclosure of bank records, where a court order will be needed and shall be issued based on a demonstrated need and adequacy of the evidence visà-vis the constitutional right to privacy.

Although some multilateral agreements (like the UN Convention on Transnational Organized Crime ${ }^{55}$ ) contain a specific provision that prohibits denial of assistance on the grounds that it involves handing out bank records, the U.S.-Brazil MLAT does not contemplate such prohibition. Nevertheless, Brazilian courts have affirmed, in more than one occasion, the validity of the assistance provided by Brazilian authorities 
comprising the disclosure of bank data made either by means of bilateral agreements or multilateral agreements. ${ }^{56}$

Brazilian courts have also affirmed the possibility of sharing information gathered in domestic investigations or criminal proceedings with authorities abroad, including bank records and tax information as happened, for instance, in an incoming request from Belgium, regarding investigations related to money laundering with precious stones. ${ }^{57}$ It must be noted that it is a common practice in Brazil that investigations involving suspicion of the commitment of tax offenses (solely or together with other offenses, like money laundering or financial crimes) are developed by the police in close cooperation with tax authorities, who usually participate in the collection of evidence, either during the execution of search and seizure warrants or during the analysis of bank records and other documents relevant for the investigation. This evidence is generally further shared and used by the tax authorities for the assessment and collection of taxes, and, as seen, can be the subject of mutual legal assistance requests with for authorities overseas.

The renowned case of a Brazilian F-Indy racer is a good example of how tax evasion investigations can lead to the exchange of information in tax matters. He was indicted, tried and finally acquitted of various counts of income tax evasion in 2008 . The prosecution charged him with defrauding the United States by using an offshore shell corporation to fraudulently conceal income received from two sources from the IRS. His attorney was also accused of participating and facilitating the schemes that led to the tax evasion. ${ }^{58}$ In this case, Brazilian and U.S. authorities worked closely during the investigation phase that was partly developed in Brazil. The Brazilian police and the Prosecution's Office helped US prosecutors and IRS authorities in the gathering of evidence, like witnesses' statements and bank records, under the BrazilU.S. MLAT provisions.

With the ratification of the Brazil-US TIEA, in March 2013, ${ }^{59}$ the exchange of information in tax matters between these countries tends to increase, as a legal tool is now in force providing grounds for close co-operation. The Agreement's scope comprises not only relevant information for tax authorities, but also for criminal purposes ${ }^{60}$ - investigation and prosecution of tax fraud and evasion - as clearly provided by article I. It shall also expedite exchange of information between tax authorities, especially considering that, in contrast with what happens with MLAs for criminal matters, the competent authorities for the Brazil-U.S. TIEA enforcement are the Minister of Finance, the Secretary of Federal Revenue or their authorized representatives (article IV, n. 1). This means that the central authority in charge of executing the requests already holds the information to be exchanged, as opposed to the Central Authority for assistance in criminal matters that must seek the information requested from law enforcement bodies or courts. One important feature provided by the agreement is the requirement, burdening the requesting State, to demonstrate that it 
was "unable to obtain the requested information by other means, except where recourse to such means would give rise to disproportionate difficulty" (article V, n. 1). If this requirement sounds like a higher standard to provide co-operation compared to requests made in other matters, it may, on the other hand, facilitate the obtaining of a court order granting access to bank records in Brazil, as the grounds of need will be given beforehand with the request itself.

\section{I RightS OF DEFENDANTS AND TARGETS}

As for the safeguard of the defendant/targets' rights if assistance is requested by the U.S. government from Brazil in criminal matters, some interesting issues arise, mainly in connection to due process safeguards of the target. ${ }^{61}$

As already mentioned, if the request is solely for obtaining public records or serving documents the liaison will be direct between central authorities (CA). But if the request implies measures restricting fundamental rights then a court's ruling will be required and some important difficulties are posed by the lack of domestic legislation regulating the granting and execution of MLA and TIEA requests in Brazil.

However, if the request is presented by means of letters rogatory containing, for instance, a judicial order for the obtaining of bank records or the seizure of assets this request will be sent to the Superior Tribunal of Justice - STJ that has issued a resolution regulating the defendant's rights during the execution of the letter rogatory. These rights encompass the right to be given notice of the request (before or after its execution, depending on the nature of the evidence to be gathered), the right to private or public counsel, the right to intervene and object to the request, the adjudication by the Special Chamber of the Court (15 judges sitting) and the right to appeal against the granting or the execution of the request.

If the request, however, comes within the direct assistance in criminal matters framework, as is the case of Brazil-U.S., it will be sent to the Brazilian central authority, which will send it to the General Attorney and then to a local Prosecutor to file the request before a first instance judge. This will happen in cases regarding evidence gathering, which, in Brazil, depends on judicial intervention, such as taking witness statements for trials, disclosure of bank records, access to electronic and oral communications and, of course, assets freezing. The same standards shall be applied under the TIEA recently passed, as the guarantees mentioned hereto apply whenever a criminal offense is under investigation or prosecution.

It is here that the lack of legislation in Brazil, regulating international assistance in criminal matters, shows its importance. ${ }^{62}$ As the STJ resolution, being an internal regulation of that Court, is not binding upon other judges who will deal with the requests, no provision grants procedural due process rights like those granted within that Court. Therefore, the target will not be given notice of the request, a public defense attorney will not be appointed, and no objection to the request will be submitted. 
The absence of legislation has left the first instance judge with considerable discretion to determine the parameters that will be applied in relation to the due process clause. This has resulted in considerable uncertainty as to how, and if, that defendant's/suspect's rights will be protected. In short, because of the lack of legislation, procedural due process rights are not protected within the direct assistance tool. 63

One of the problems arising from this situation is what is usually referred to as the "black hole" in the MLA. Consider, for example, a request coming from the U. S., aiming to obtain the bank records of an individual or corporation in Brazil. As mentioned, a ruling of a judge will be needed, ${ }^{64}$ and one based on well-grounded elements of suspicion of the possible commission of a crime and the strict need for the measure to proceed with the investigation. If a Brazilian judge in a MLA grants the order with no observation of the local legal requirements, and the person is not allowed to object to the request before the records are turned over to the U. S. authorities, it will no longer be possible to argue the inadmissibility of this evidence, since Brazil no longer has jurisdiction and in the U. S. there is no need for a judicial ruling based on such strict requirements for the lifting of the bank secrecy veil.

Another important issue regarding the lack of local regulation is the impossibility to argue the violation of the public order in granting the request. As the individual does not participate in the granting and execution of the request, he/she cannot challenge the MLA's legality on the grounds of, for example, politically motivated prosecution or public order violation (order public). 65

For the same reason, the lack of domestic regulations, the same challenges shall be expected regarding requests made under the Brazil-U.S. TIEA.

\section{FINAL REMARKS}

Brazilian legislation and institutional framework support the EOI policies. The RFB has wide-ranging access powers to obtain information for international exchange purposes and has legal tools to coerce the production of such information, including assets ownership, identity, bank and accounting data.

Brazil is clearly making attempts to join the international community, as its efforts against tax evasion through the exchange of information in tax matters show. It has ratified 30 Double Tax Bilateral - DTB, and signed seven Tax Information Exchange Agreements - TIEAs. ${ }^{66}$ It has also launched a taskforce to work with the aim of meeting the international standards draw by the Global Forum.

Brazilian tax authorities have wide and timely electronic access to relevant information for tax assessment and collection, and this access shall increase with three electronic initiatives taken in the last few years. SPED, NF-e and DIMOF are digital tools that provide the tax administration, in some cases in real time, with a wide range 
of information relevant to the assessment and collection of taxes. This information can further be exchanged with foreign tax authorities.

These tools, in addition to the information already given by taxpayers, financial institutions and non-financial institutions to the tax administration bodies, provide the Brazilian authorities with all the information needed to swiftly grant assistance requests from tax authorities overseas.

Although Complementary Law n. 105/2001 grants the RFB with wide powers to have access to bank records, the Brazilian Supreme Court recently delivered a ruling demanding a court order to the disclosure of such records by banks. In an Extraordinary Appeal, the plenary of the Court ruled that the provision granting the RFB with powers to direct access to bank records for tax purposes is in conflict with constitutional rules protecting individual privacy and shall only be enforced by means of a court order authorizing the disclosure of such information. If a mutual legal assistance request is made seeking such kind of information, either under an MLAT or a TIEA, a court ruling will be needed.

Nevertheless, we conclude that Brazil is following the right path to implement the international exchange of information standards. Its next steps shall note that the timeframe to bring the treaties signed into force is not yet satisfactory, and the harmonization of Brazilian legislation with the Supreme Court's decision on bank secrecy is of paramount importance to adequate the EOI instruments with the constitutional right to privacy.

NOTES

* This paper was written on the occasion of the International Tax Enforcement Conference organized by the TAXATION - A Section of the American Bar Association, the IBA - Tax Committee, and the TEI - Tax Executives Institute, Inc., held on November 8-9, 2012, in New York, NY. The article submitted at the event was reviewed and updated for this publication.

1 For further information: OECD (1998) - Harmful Tax Competition: an emerging global issue, OECD Publishing.

2 For further information: CASTELLS, Manuel. The rise of the Network Society. Oxford: Blackwell, 2000.

3 Second Conference on the Fight against International Tax Fraud and Evasion by promoting Transparency and Exchange of Information in Tax Matters - Berlin - June 23, 2009. 
4 Brazil is not yet a member of the OECD. In May 2007, though, OECD countries agreed to offer a programme of "enhanced agreement" to Brazil, among other countries (see: <http://www.oecd.org/about/ membersandpartners/>).

5 OECD Draft Double Taxation Convention on Income and Capital (1963).

6 Article 26 - Exchange of Information:

"1. The competent authorities of the Contracting States shall exchange such information as is foreseeably relevant for carrying out the provisions of this Convention or to the administration or enforcement of the domestic laws concerning taxes of every kind and description imposed on behalf of the Contracting States, or of their political subdivisions or local authorities, insofar as the taxation thereunder is not contrary to the Convention. The exchange of information is not restricted by Articles 1 and 2.

2. Any information received under paragraph 1 by a Contracting State shall be treated as secret in the same manner as information obtained under the domestic laws of that State and shall be disclosed only to persons or authorities (including courts and administrative bodies) concerned with the assessment or collection of, the enforcement or prosecution in respect of, the determination of appeals in relation to the taxes referred to in paragraph 1, or the oversight of the above. Such persons or authorities shall use the information only for such purposes. They may disclose the information in public court proceedings or in judicial decisions. Notwithstanding the foregoing, information received by a Contracting State may be used for other purposes when such information may be used for such other purposes under the laws of both States and the competent authority of the supplying State authorizes such use.

3. In no case shall the provisions of paragraphs 1 and 2 be construed so as to impose on a Contracting State the obligation:

a) to carry out administrative measures at variance with the laws and administrative practice of that or of the other Contracting State;

b) to supply information which is not obtainable under the laws or in the normal course of the administration of that or of the other Contracting State;

c) to supply information which would disclose any trade, business, industrial, commercial or professional secret or trade process or information the disclosure of which would be contrary to public policy (ordre public).

4. If information is requested by a Contracting State in accordance with this Article, the other Contracting State shall use its information gathering measures to obtain the requested information, even though that other State may not need such information for its own tax purposes. The obligation contained in the preceding sentence is subject to the limitations of paragraph 3 but in no case shall such limitations be construed to permit a Contracting State to decline to supply information solely because it has no domestic interest in such information.

5. In no case shall the provisions of paragraph 3 be construed to permit a Contracting State to decline to supply information solely because the information is held by a bank, other financial institution, nominee or person acting in an agency or a fiduciary capacity or because it relates to ownership interests in a person".

7 Andorra, Anguilla, Antigua and Barbuda, Argentina, Aruba, Australia, Austria, Bahamas, Bahrain, Barbados, Belgium, Belize, Bermuda, Botswana, Brazil, British Virgin Islands, Brunei Darussalam, Canada, Cayman Islands, Chile, China, Colombia, Jersey, Kenya, Korea, Latvia, Liberia, Liechtenstein, Lithuania, Luxembourg, Macao (China), Malaysia, Malta, Marshall Islands, Mauritania, Mauritius, Mexico, Monaco, Montserrat, Morocco, Nauru, Netherlands, New Zealand, Nigeria, Niue, Norway, Cook Islands, Costa Rica, Curacao, Cyprus, Czech Republic, Denmark, Dominican Republic, El Salvador, Estonia, Finland, Yugoslavia Republic of Macedonia, France, Georgia, Germany, Ghana, Gibraltar, Greece, Grenada, Guatemala, Guernsey, Hong Kong (China), Hungary, Iceland, India, Indonesia, Panama, Philippines, Poland, Portugal, Qatar, Russia, St. Kitts and Nevis, St. Lucia, Sint Maarten, St. Vincent and the Grenadines, Samoa, San Marino, Saudi Arabia, Seychelles, Singapore, Slovakia, South Africa, Spain, Sweden, Switzerland, Trinidad and Tobago, Tunisia, Turkey, Turks and Caicos Islands, United Arab Emirates, Ireland, Isle of Man, Israel, Italy, Jamaica, Japan, United Kingdom, United States, U.S. Virgin Islands, Uruguay, Vanuatu, European Union. Available at <www.oecd.org/tax/transparency/Information520Brief_27\% 20June\%202012.pdf>.

8 Asian Development Bank, Commonwealth Secretariat, European Bank for Reconstruction and Development, European Investment Bank, Inter-American Development Bank, International Finance Corporation, International Monetary Fund and World Bank. For further information: <www.oecd.org/tax/transparency/ Information520Brief_27\%20June\%202012.pdf>.

9 See: <www.oecd.org/tax/transparency/Information520Brief_27\%20June\% 202012.pdf>. 
10 Furthermore at: <www.oecd.org/tax/transparency/Information520Brief_27\%20June\% 202012.pdf>.

11 See: <www.oecd.org/tax/transparency/Information520Brief_27\%20June\% 202012.pdf>.

12 Further information available at: <www.oecd.org/tax/transparency $>$.

13 Joint Audits consist of a process where two or more countries gather together to audit a multinational company.

14 Further information available at: <http://www.deloitte.com/view/en_US/us/Services/tax/930c9948e681 a210VgnVCM100000ba42f00aRCRD.htm>.

15 Further information available at: <http://www.kpmg.com/br/pt/estudos_analises/artigosepublicacoes/ paginas/release-fatca.aspx $>$.

16 Further information available at: <http://www.treasury.gov/press-center/press-releases/Pages/tg1759.aspx>.

17 Conselho de Desenvolvimento Econômico. Anais do Seminário Internacional sobre Justiça Fiscal. August 10, 2011, p. 34.

18 Argentina; Austria; Belgium; Canada; Chile; China; Czech Republic and Slovakia; Denmark; Ecuador; Finland; France; Germany (agreement not in force since December $1^{\text {st }}$, 2006); Hungary; India; Israel; Italy; Japan; Korea; Luxembourg; Mexico; Netherlands; Norway; Peru; Philippines; Portugal; South Africa; Spain; Sweden; Ukraine. Further information available at: <http://www.receita.fazenda.gov.br/principal/ingles/Acordo/ DuplaTributDefault.htm>.

19 The agreement between Brazil and United States of America (20/03/2006) was brought into force by Decree n. 8.003, issued on May 15, 2013. However agreements between Brazil and, United Kingdom (28/07/2012), Uruguay (24/10/2012), Bermuda (29/10/2012), Jersey (28/01/2013), Guernsey (06/02/2013), and The Cayman Islands (19/03/2013) are still pending ratification by the Brazilian Congress (available at: <http://eoi-tax.org/ jurisdictions/BR\#agreements>.

20 "Art. $4^{\circ}$ A República Federativa do Brasil rege-se nas suas relações internacionais pelos seguintes princípios: IX cooperação entre os povos para o progresso da humanidade [...]."

21 See article 37, XXII, Brazilian Constitution.

22 "Art. 199. A Fazenda Pública da União e as dos Estados, do Distrito Federal e dos Municípios prestar-se-ão mutuamente assistência para a fiscalização dos tributos respectivos e permuta de informações, na forma estabelecida, em caráter geral ou específico, por lei ou convênio. Parágrafo único. A Fazenda Pública da União, na forma estabelecida em tratados, acordos ou convênios, poderá permutar informações com Estados estrangeiros no interesse da arrecadação e da fiscalização de tributos."

23 Instruction n. 203 of Ministry of Finance: "Art. 50. À Coordenação-Geral de Cooperação e Integração Fiscal Cocif compete gerenciar e integrar as atividades relacionadas com o planejamento, coordenação, desenvolvimento e avaliação da execução das ações de cooperação e integração da gestão fazendária e com a troca de informações e dados fiscais entre a RFB e as administrações tributárias dos Estados, do Distrito Federal e dos Municípios, e outros organismos estatais, acompanhar a execução e avaliar protocolos e convênios, elaborados em articulação com as áreas operacionais da RFB, além de coordenar e alocar as atividades das gerências sob sua subordinação. Art. 51. Às Gerências de Cooperação e Integração Fiscal - Gcif1, 2 e 3 compete, em ações específicas, gerenciar e integrar as atividades relacionadas com o planejamento, coordenação, desenvolvimento e avaliação da execução das ações de cooperação e integração da gestão fazendária e com a troca de informações e dados fiscais entre a RFB e as administrações tributárias dos Estados, do Distrito Federal e dos Municípios, e outros organismos estatais”.

24 Instruction n. 203 of Ministry of Finance "Art. 150. À Divisão de Relações Institucionais Internacionais - Dirin compete: I - elaborar propostas, conduzir e coordenar as negociações relativas a acordos e convênios de cooperação técnica internacional em matérias tributária e aduaneira; $I I$ - em articulação com as demais áreas da RFB: a) acompanhar e avaliar as atividades a serem desenvolvidas no âmbito dos acordos e convênios de cooperação técnica internacional de que trata o inciso I; b) planejar, coordenar e avaliar a visita ao País de delegações oriundas de outros países e de organismos internacionais [...]”. 
25 National Tax Code, under article 197, provides an exception for professional secrecy with regard to "facts that the holder is legally obliged to keep confidential due to his or her position, function, ministry, activity or profession". This exception only applies to persons subjected to professional secrecy duties, such as attorneys, physicians and clerics.

26 Law n. 2.354/54, article 7; Decree-Laws ns. 5.844/43, article 123, and 1.718/79, article 2; and National Tax Code, articles 195 and 197; RIR/99, articles 927 and 928.

27 Law n. 9.430/96, article 35; RIR/99, article 915.

28 See article 5, Brazilian Constitution.

29 Decree-Law n. 486/69, article 4; National Tax Code, articles 173, 174, 195, and 197; Complementary Law n. 123/06, article 26, II; Normative Instruction RFB n. 983/09, article 27; Law n. 9.613/98.

30 Decree-Law n. 486/69, article 4; National Tax Code, articles 173, 174, 195, and 197; Complementary Law n. 123/06, article 26, II; Normative Instruction RFB n. 983/09, article 27; Law n. 9.613/98.

31 Which are provided in Article 26 of the OECD Model Tax Convention and Article 8 of the OECD Model TIEA.

32 See article 5, XII, Brazilian Constitution.

33 Until 2001, bank confidentiality was protected under article 38 of Law n. 4.595/64.

34 This information covers investigations in both civil and criminal tax cases.

35 A set of articles addressing tax and bank confidentiality in Brazil can be found at: Saraiva Filho; Guimarães (2011).

36 See Decree n. 3.724/01, article 4, paragraph 2.

37 See Decrees ns. 70.235/72, article 7, and 7.574/11, article 33.

38 See Complementary Law n. 105/01 and Decree n. 3.724/01, article 3, X.

39 The absence of domestic tax interest rule happens when a contracting party can only provide information to another contracting party if it has an interest in the requested information for its own tax purposes.

40 Originally named Conselho de Controle de Atividades Financeiras - COAF.

41 ADIs ns. 2.386 (2001), 2.390 (2001), 2.397 (2001), 4.006 (2008), and 4.010 (2008).

42 Decision taken on 15 December 2010.

43 Zagaris calls attention to the fact that, in terms of enforcement cooperation, there is a historic wide range of subjects between US and Brazil, such as memorandum of understanding on securities enforcement and commodities futures cooperation, a customs cooperation agreement, a mutual assistance in criminal matters treaty, framework agreement on cooperation in the peaceful uses of outer space, an extradition treaty, an air transport agreement, an agreement regarding defense cooperation, an antitrust enforcement cooperation agreement and a strong cooperation against drug trafficking (see ZAGARIS, 2013, p. 1).

44 Originally named: Sistema Público de Escrituração Digital.

45 For further more: <http://www1.receita.fazenda.gov.br/sistemas/sped-contabil/o-que-e.htm>.

46 Only companies and partnership taxed under the actual profit regime are obliged to adopt the SPED-Accounting.

47 Tax of circulation of goods and services. 
48 Tax of industrialized goods.

49 Originally named: Nota Fiscal Eletrônica.

50 Updated by Normative Instruction RFB n. 1092/2010.

51 See: <http://www1.receita.fazenda.gov.br/sobre-o-projeto/beneficios.htm>.

52 The taskforce will comprise representatives of the FRB, Council for Financial Activities Control - COAF, Brazilian Central Bank, Securities Exchange Commission - CVM, Secretary of Justice, Federal Police and Trade Registration National Department - DNRC.

53 For a general overview of the Brazilian legal framework on mutual legal assistance in criminal matters, see: Sousa (2008, p. 297-325).

54 Brazil also has other bilateral agreements in criminal matters with Switzerland, France, China, Colombia, Italy, Canada, Spain, among others.

55 Brazil has ratified this Convention and it entered into force on the domestic level by way of the Decree $\mathrm{n}$. 5015, of March 12, 2004. Article 18, par. 8, says: "States Parties shall not decline to render mutual legal assistance pursuant to this article on the grounds of bank secrecy".

56 Superior Tribunal of Justice, CR 438/Belgium, CR 998/Italy.

57 Superior Tribunal of Justice, CR 2069, May 2007.

58 A press release from the DOJ can be found at: <http://www.justice.gov/tax/txdv08884.htm>.

59 Decree n. 8.003, May 15, 2013.

60 Zagaris stresses that both countries decided that such agreement would be a legal tool to prevent, investigate and prosecute tax crimes, since the United States is one of the main sources for Brazilian tainted money. Cf. Zagaris (2013, p. 2).

61 A comprehensive examination of the due process safeguards in the field of mutual legal assistance in criminal matters in Brazil can be found in Bechara (2011).

62 For some particular aspects of this issue, see: Madruga (2005, p. 291-311).

63 Before coming to this conference and in order to have a broader view of the various courts practice in Brazil, I interviewed some Brazilian judges used to receiving legal assistance requests and it became apparent that in practice their judicial discretion generally leads to there being little or no application of procedural due process rights on behalf of targets/defendants.

64 This issue was recently discussed in a polemic Brazilian case regarding a money laundering investigation, in which a State's Prosecutor requested, directly through the Brazilian CA, via MLAT, bank information of some people investigated in the US. These people filed an injunction against the request and obtained a ruling from a State Court of Appeals forbidding the request because, among other reasons, there was no judicial authorization for this discovery in Brazil. The Prosecutor filed a further injunction before the STJ, but this court never reached a final decision as the case was quashed in the first instance on other grounds (see STJ, SS 2382, 2011).

65 For further discussion on the imbalance between prosecution and defense's ability to use the U.S.-Brazil MLAT see: Zagaris (2010); and also Aras (2010, p. 321-400). A broader view regarding human rights in international cooperation in criminal matters can be found in Hoek (2005).

66 Comprehensive information can be found at: <http://www.eoi-tax.org/jurisdictions/BR\#agreements>. 


\section{REFERENCES}

ARAS, Vladimir. O sistema de cooperação penal Brasil/EUA. In: BALTAZAR JÚNIOR, José Paulo; LIMA, Luciano Flores de. Cooperação jurídica internacional em matéria penal. Porto Alegre: Verbo Jurídico, p. 321-400, 2010. BECHARA, Fábio Ramazzini. Cooperação jurídica internacional em matéria penal: eficácia da prova produzida no exterior. São Paulo: Saraiva, 2011.

BLOCH, Henry; HEILEMANN, Cyril. International Tax Relations. The Yale Law Journal, v. 55, n. 5, 1946.

CASTELLS, Manuel. The rise of the Network Society. Oxford: Blackwell publishers. 2000.

CONSELHO de Desenvolvimento Econômico. Anais do Seminário Internacional sobre Justiça Fiscal. August, 10, 2011. GRECO, Marco Aurélio. Troca de Informações Fiscais. In: SARAIVA FILHO, Oswaldo Othon de Pontes; GUIMARÃES, Vasco Branco (Coords.). Sigilo Bancário e Fiscal - Homenagem ao jurista José Carlos Moreira Alves. Belo Horizonte: Forum, p. 175-187, 2011.

HOEK, Aukje A. H. van, LUCHTMAN, Michiel J. J. P. Transnational cooperation in criminal matters and the safeguarding of human rights. Ultrecht: Ultrecht Law Review, v. 1, issue 2 (December) 2005.

MADRUGA, Antenor. O Brasil e a jurisprudência do STF na idade media da cooperação jurídica internacional. Revista Brasileira de Ciências Criminais, v. 54, p. 291-311, 2005.

OECD. Harmful Tax Competition: an emerging global issue, OECD Publishing, 1998.

The Global Forum on Transparency and Exchange of Information for Tax Purposes (Background Information Brief, OECD, Paris, 2 May 2011), p. 16, 2011.

Global Forum on Transparency and Exchange of Information for Tax Purposes Peer Review: Brazil 2012: Phase 1: Legal and Regulatory Framework, OECD Publishing, 2012.

RODOTTÀ, Stefano. Conferência: Globalização e Direito. Procuradoria-Geral Do Município do Rio de Janeiro - PGM. 11 mar. 2003.

SARAIVA FILHO, Oswaldo Othon de Pontes; GUIMARÃES, Vasco Branco (Coord.). Sigilos bancário e fiscal. Belo Horizonte: Fórum, 2011.

SOUSA, Carolina Yumi. Cooperação jurídica internacional em matéria penal: considerações práticas. Revista Brasileira de Ciências Criminais, v. 71, p. 297-325, 2008.

PRIDEAUX, John. The Economist. Brazil takes off. November 12, 2009.

ZAGARIS, Bruce. International white collar crime: cases and materials. New York: Cambridge, 2010a.

U.S.-Brazil and international evidence gathering: the need for a fair balance. Roundtable at Barbosa, Müssnich e Aragão, São Paulo, September 1, 2010 b. Brazil-U.S. TIEA Takes Effect and Presages Significant New Tax Enforcement Cooperation. Tax Notes International. June 24, 2013.

Heloisa Estellita

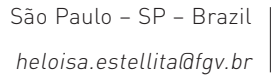

Professor of Law at Getulio Vargas Foundation's São PaUlo LaW School.

ONGOING POST-DOCTORAL RESEARCH AT LUDWIG-MAXIMILIANS UNIVERSITÄT MÜNCHEN.

DOCTOR OF LAWS, UNIVERSITY OF SÃo PAULO. Master of LaWs, UNESP - São Paulo State University. BAchelor of LaWs, University of Ribeirão Preto.

\section{Frederico Silva Bastos}

\footnotetext{
São Paulo - SP - Brazil frederico.bastoslagvmail.br
}

\section{ATTORNEY.}

Professor of the Graduate Program at Getulio Vargas Foundation's São Paulo LaW School.

MASter of LAWS, Getulio Vargas Foundation's São PaUlo LaW School.

Former RESEARCHER AT CENTER FOR FisCAL StUdies (NEF). 
